\title{
Grazing management for regeneration of balansa clover in a cocksfoot pasture
}

\author{
D.P. MONKS, D.J. MOOT, M.C. SMITH and R.J. LUCAS \\ Agriculture and Life Sciences Division \\ Lincoln University, Canterbury 7647, New Zealand
}

Monksd2@lincoln.ac.nz

\begin{abstract}
'Bolta' and 'Frontier' balansa clover seedlings were counted through two autumns following a large seed set in November 2006, from monocultures sown in a dryland environment in Canterbury. Following rain on 5 January 2007, $65 \%$ of 'Bolta' seed and 54\% of 'Frontier' seed emerged. Approximately $11 \%$ of seed produced in 2006 remained in the soil in April 2008. These results highlight the regeneration potential of balansa clover. In a separate dryland grazing experiment at Lincoln University, six 'Bolta' balansa clover/cocksfoot plots were managed individually during five spring flowering periods to provide different amounts of seed. The total annual dry matter production of the balansa clover was dependent on this grazing management. Specifically, clover content in those cocksfoot pastures averaged above $30 \%$ for the 3 years following a major seeding event. Closing the balansa clover/cocksfoot pasture on 6 September to allow flowering after a February sowing, or no spring grazing after a late May sowing, provided sufficient seed for successful re-establishment of the balansa clover for the next 3 years. In contrast, when the February sown plots were closed on 24 October, only half as much clover was produced in the following years. Thus, successful regeneration of balansa clover will require management for seed production in the establishment year and then on a 3 year cycle.
\end{abstract}

Keywords: annual legumes, balansa clover, Dactylis glomerata, false break, seed bank, spring closing date, Trifolium michelianum, Trifolium subterraneum.

\section{Introduction}

Balansa clover (Trifolium michelianum Savi) is a Mediterranean species that may complement white ( $T$. repens) and subterranean (T. subterraneum) clovers in pasture mixtures for dry eastern regions of New Zealand. Balansa is a top flowering annual clover that is capable of contributing over $4 \mathrm{t} \mathrm{DM/ha/year} \mathrm{(36 \% )} \mathrm{to} \mathrm{a} \mathrm{dryland}$ cocksfoot pasture in the second year following a heavy seed set.

In southern Australia, the cereal cropping rotation has relied on annual temperate legumes and medics as the main source of nitrogen input for over 60 years (Dear 2003 ) with balansa clover used for grazing, hay, silage or green manure in over 1.5 million ha (Craig \& Ballard 2000). Balansa clover is used as a monoculture in these systems so hardseededness ensures it re-establishes the year after the cropping phase. The balansa clover can then be hard grazed after autumn emergence through to the beginning of flowering in the spring when it is spelled to reseed. A hard 'clean-up' grazing in early summer ensures re-establishment in the following autumn (Craig \& Ballard 2000). In New Zealand, pastoral farming requires set-stock management during lambing which may limit the potential use of top flowering annual clovers. Also, eastern New Zealand does not have a true Mediterranean climate with a guaranteed summer drought. Annual clovers are disadvantaged by wet summers through cool soil temperatures that reduce seed softening and promote grass growth which increases competition and reduces space for annual clover reestablishment (Craig \& Ballard 2000).

In the establishment phase of the MaxClover cocksfoot (Dactylis glomerata) grazing experiment referred to in this paper, balansa clover produced $2.3 \mathrm{t} \mathrm{DM} / \mathrm{ha}(\mathrm{P}<0.05)$ compared with $1.1 \mathrm{t} \mathrm{DM} /$ ha for subterranean clover from 18 February to 8 September (C. Buckley unpublished). The balansa out-yielded subterranean clover when there was only moderate grass competition. However, over time, subterranean clover was more reliable at the MaxClover site (Mills et al. 2008).

This study aims to define pasture grazing management options that maintain balansa clover in a perennial grass/ annual clover pasture. To do this, two separate experiments are reported. The first determines the annual pattern of balansa clover seedling recruitment after an initial heavy seed set, and the second measures balansa clover herbage production in a cocksfoot pasture after manipulation of seed set through early and late spring closing.

\section{Methods}

\section{Experiment 1. Seedling recruitment in two cultivars of balansa clover}

This field experiment was located at Lincoln University on a Wakanui silt loam (Udic Ustochrept, USDA Soil Taxomony) soil with a plant available water capacity (Brown et al. 2003) of $150-200 \mathrm{~mm} / \mathrm{m}$ and $2.3 \mathrm{~m}$ to underlying gravels.

Three replicate monocultures of early flowering 'Frontier' and later flowering 'Bolta' balansa clover were sown into 6 by $2.1 \mathrm{~m}$ plots in a fallowed seed bed on 16 January 2006 at $6 \mathrm{~kg} / \mathrm{ha}$ of viable seed in $150 \mathrm{~mm}$ rows 
Figure 1 Percentage of 'Bolta' ( $\bigcirc$ ) and 'Frontier' ( $\bullet$ ) balansa clover seeds remaining in the soil after seedling emergence and removal following rain events at Lincoln University, Canterbury. Daily rainfall is from Broadfields Meteorological Station, $\sim 2 \mathrm{~km}$ north of the experimental site. Error bar of 1.61 represents the s.e. of seeds remaining (\%).

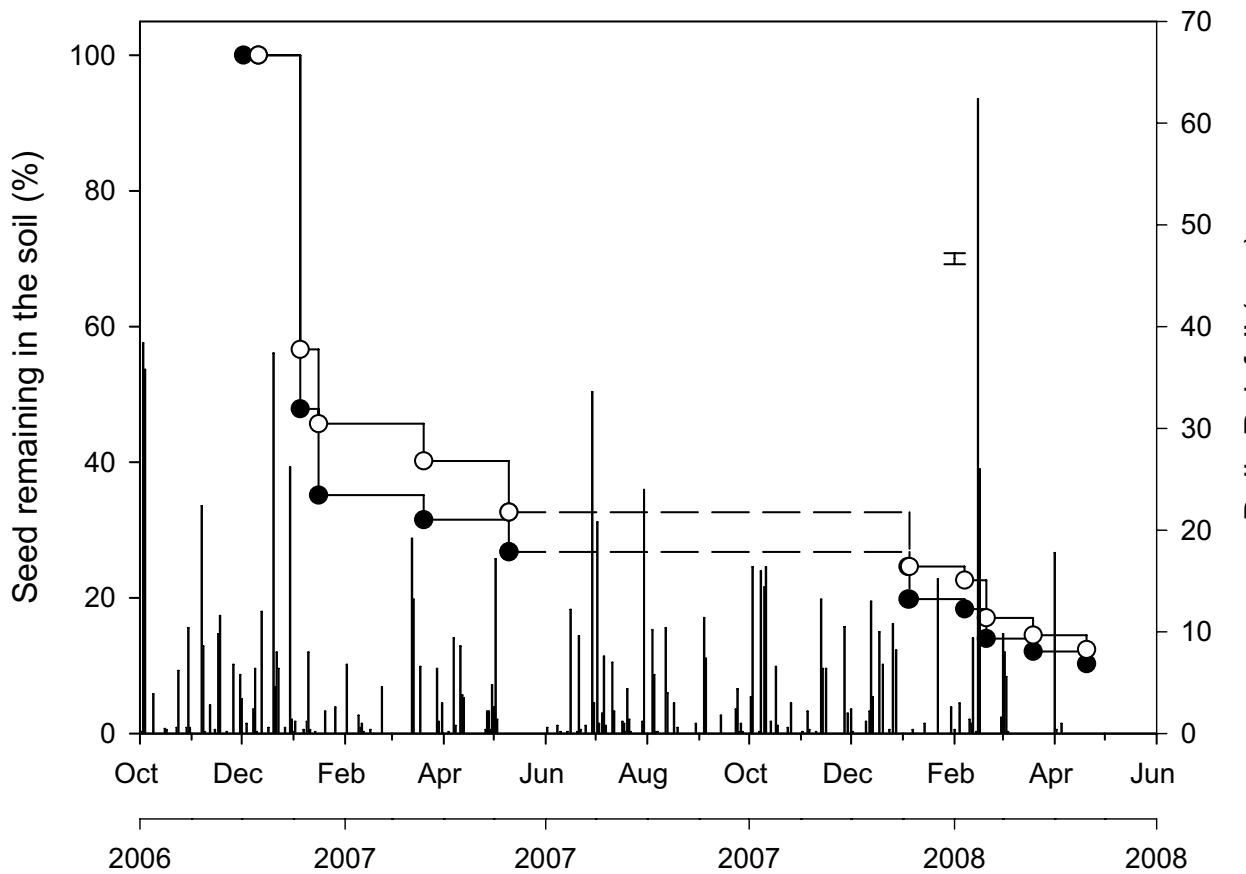

using an Øyjood cone seeder. This gave potential populations of 520 and 670 seedlings $/ \mathrm{m}^{2}$ for 'Frontier' and 'Bolta' based on thousand seed weight (TSW) of $1.15 \mathrm{~g}$ and $0.90 \mathrm{~g}$ and laboratory germination of $89 \%$ and $23 \%$, respectively.

The first germinating rains of $16 \mathrm{~mm}$ came on 5 February 2006. Between 6 February and 23 April, only $77 \mathrm{~mm}$ of rain fell, so irrigation to field capacity was applied on 13 and 20 April 2006 to ensure survival of the seedlings. The experiment was sprayed with Pulsar (200 $\mathrm{g} / \mathrm{L}$ bentazone and $200 \mathrm{~g} / \mathrm{L} \mathrm{MCPB}$ ) at $5 \mathrm{~L} /$ ha and Gallant (100 g/L haloxyfop and $347 \mathrm{~g} / \mathrm{L}$ diethylene glycol) at $2.5 \mathrm{~L} /$ ha on 28 August 2006 to control broad leaf weeds including shepherd's purse (Capsella bursa-pastris) and fathen (Chenopodium album) and grass weeds including Poa annua. The plots were left ungrazed to allow maximum flowering and seed set. After seed had been shed from seed heads, the remaining mature herbage was cut to a stubble height of $80 \mathrm{~mm}$ on 11 December 2006 using a rotary mower without the catcher. The mown material, which consisted mostly of stems, was then hand raked off the plots.

Rainfall between 20 and 23 December 2006 of $56 \mathrm{~mm}$ (Fig. 1) led to the germination and emergence of dense populations of balansa clover seedlings. Six $100 \mathrm{x}$ $100 \mathrm{~mm}$ quadrats per plot were fixed to the soil on 5 January 2007 and seedlings were counted and removed.
Subsequent re-counts were made from these quadrats following rain events through the summer/autumn until 10 May 2007. The experimental area was then knapsack sprayed with Roundup Transorb (glyphosate $540 \mathrm{~g} /$ $\mathrm{L}$ a.i.) at $20 \mathrm{ml} / \mathrm{L}$ water on 22 May 2007 to kill the clover and prevent flowering and seed production from the site in spring/summer 2007 (Year 2). Emergence counts from the seed set in 2006 continued after $56 \mathrm{~mm}$ of rain fell between 10 and 28 December 2007. Counting continued until 20 April 2008 when soil from fixed quadrats was dug out to a depth of $40 \mathrm{~mm}$ and any remaining balansa clover seed was hand sieved from the 36 soil samples.

Data from this experiment were analysed as a randomised complete block experiment by analysis of variance using GenStat (v10). All analyses were performed on untransformed plot data for each cultivar. Total seed set was calculated as the cumulative number of seedlings removed from the fixed quadrats plus seeds remaining in the soil. In this experiment all seed was considered accounted for by either emergence or hardseededness with no allowance for predation or decay.

Experiment 2. Grazing management and balansa clover productivity

'Bolta' balansa clover (3.5 kg/ha) and 'Denmark' subterranean clover (Trifolium subterraneum) (10 kg/ 
Table 1 The day of last grazing (spring closing date (C)) for balansa clover pastures sown with cocksfoot in a grazing experiment on 18 Feb 2002 (Plots 1-4) and 6 May 2003 (Plots 5\&6) at Lincoln University, Canterbury.

\begin{tabular}{cccccccccccccc}
\hline \multicolumn{1}{c}{} & & \multicolumn{1}{c}{ 1 } & \multicolumn{1}{c}{ Pasture Plot No. } \\
\hline Year & C & O & C & O & C & O & C & O & C & O & C & O \\
\hline 2002 & $6 / 09$ & $1 / 01$ & $23 / 09$ & $8 / 01$ & $24 / 10$ & $16 / 01$ & $10 / 10$ & $10 / 01$ & - & - & - & - \\
2003 & $28 / 10$ & $23 / 12$ & $3 / 11$ & $23 / 12$ & $7 / 11$ & $29 / 12$ & $12 / 11$ & $29 / 12$ & - & $22 / 12$ & - & $22 / 12$ \\
2004 & $29 / 10$ & $19 / 12$ & $4 / 10$ & $10 / 12$ & $11 / 10$ & $10 / 12$ & $15 / 10$ & $15 / 12$ & NC & NC & $25 / 10$ & $15 / 12$ \\
2005 & NC & NC & NC & NC & NC & NC & NC & NC & NC & NC & NC & NC \\
2006 & $27 / 10$ & $3 / 01$ & $5 / 11$ & $11 / 01$ & $29 / 10$ & $20 / 01$ & $22 / 10$ & $30 / 01$ & $25 / 10$ & $26 / 12$ & $8 / 11$ & $19 / 12$ \\
2007 & NC & NC & NC & NC & NC & NC & NC & NC & NC & NC & NC & NC \\
\hline
\end{tabular}

Note: $\mathrm{NC}$ is no closing for flowering and reseeding. $\mathrm{C}$ is closing date, $\mathrm{O}$ is opening grazing date when grazing recommenced. Plots 5 and 6 were first grazed on 22 December 2003. The interval between $\mathrm{C}$ and $\mathrm{O}$ indicates the length of spelling time for each plot.

ha) were sown separately in a mixture with 'Vision' cocksfoot $(4 \mathrm{~kg} / \mathrm{ha})$ on 18 February 2002 into four 0.05 ha fenced plots as two of the six mixtures sown as part of a larger MaxClover dryland grazing experiment (Brown et al. 2006) at Lincoln University, Canterbury, New Zealand. Two additional replicates of the six grazing experiment treatments were sown at the same site on 6 May 2003. Plant available water capacity (PAWC) for the top metre averages $160-180 \mathrm{~mm} / \mathrm{m}$ and between 0.8 and $1.4 \mathrm{~m}$ to underlying gravels (A. Mills pers. comm.). All pasture types within the larger experiment were grazed to balance animal and pasture requirements. For balansa clover pastures, emphasis was placed on maximising spring clover content through rotational grazing from late August with three flocks grazing two paddocks each in 10-14 day rotations. This changed to two flocks grazing three paddocks at 15-18 day rotations in late September. Each pasture was periodically closed in spring to allow the clover to re-seed. The timing and frequency of closure, and hence re-seeding, differed amongst the six balansa/cocksfoot plots (Table 1). This enabled the effects on balansa clover seedling recruitment and herbage productivity to be investigated. Intensive summer grazing with ewes was used to remove herbage and open the sward for seedling emergence (Craig \& Ballard 2000). Dry matter production and botanical composition were measured under exclosure cages. Caged areas $\left(1 \mathrm{~m}^{2}\right)$ were mown to $30 \mathrm{~mm}$ height prior to cage placement and moved to a freshly mown area every 28 days. Total dry matter production of each plot was analysed using a oneway ANOVA; statistical analysis was not possible for plot by year means because each of the six fenced plots was managed differently.

\section{Results}

\section{Experiment 1. Seedling recruitment}

On 5 January 2007, seedling counts averaged 24,000 plants $/ \mathrm{m}^{2}$ and by 16 January, $65 \%$ of 'Bolta' and $54 \%$ of 'Frontier' seeds had germinated (Fig. 1). When emergence counts ceased on 10 May there were still 27\% and $37 \%$ of seed remaining in the soil for 'Bolta' and 'Frontier', respectively. Emergence counts recommenced on 4 January 2008 and showed a similar pattern of seed softening to that recorded in 2007. Accumulating the total number of seedlings emerged and seeds remaining in the soil to 20 April 2008 equated to $~ 50,000$ seeds $/ \mathrm{m}^{2}$, or $\sim 600 \mathrm{~kg}$ seed/ha, produced from the single flowering in spring 2006 . Approximately $11 \%$ of that population remained as hard seed in April 2008 for both cultivars.

\section{Experiment 2. Grazing management and balansa clover productivity}

Of the four plots sown in 2002, Plot 1 had the earliest closure date in 2002 (Table 1) and produced the most $(\mathrm{P}=0.006)$ dry matter and clover content of the four balansa clover pastures. Total herbage production of this plot averaged $9.3 \mathrm{t} \mathrm{DM} / \mathrm{ha} /$ year with between 2.2 and $4.3 \mathrm{t} \mathrm{DM} /$ ha of balansa clover (Fig. 2). The exception was in 2006 when DM production decreased to $<0.5 \mathrm{t} /$ ha but it then recovered to $>3 \mathrm{t} / \mathrm{ha}$ in 2007 after an October closing in 2006 (Table 1). None of the other plots recovered in 2007 (Fig. 2). Balansa contributed an average of $28 \%$ to the total annual dry matter production over 6 years across all four plots.

The later sown Plot 5 (no grazing and full flowering in 2003, but no seed production in 2004 or 2005 (Table 1)) produced $<0.5 \mathrm{t} / \mathrm{ha}$ of clover dry matter in 2006 and 2007, after producing $\sim 2.5 \mathrm{t} / \mathrm{ha} /$ year in the previous 2 years (Fig. 3). In contrast, Plot 6 which also had no grazing and full flowering in 2003, recovered from $<1.0$ $\mathrm{t} / \mathrm{ha}$ in 2006 to almost $3 \mathrm{t} / \mathrm{ha}$ of balansa in 2007 after reseeding opportunities in 2004 and 2006. Subterranean clover production in plots adjacent to balansa Plots 5 and 6 was always greater than balansa. The Sub clover also decreased in 2006 to $\sim 1.6 \mathrm{t} \mathrm{DM} /$ ha but recovered in 2007 to produce more than $4.2 \mathrm{t} \mathrm{DM} /$ ha (Fig. 3). Mean subterranean clover production in the cocksfoot pasture during years 2-5 was $\sim 3.8 \mathrm{t} \mathrm{DM} / \mathrm{ha} /$ year. 
Figure 2 Balansa clover yield component of total annual dry matter yields for 6 years from four cocksfoot based pastures sown in February 2002 in the MaxClover experiment at Lincoln University, Canterbury.

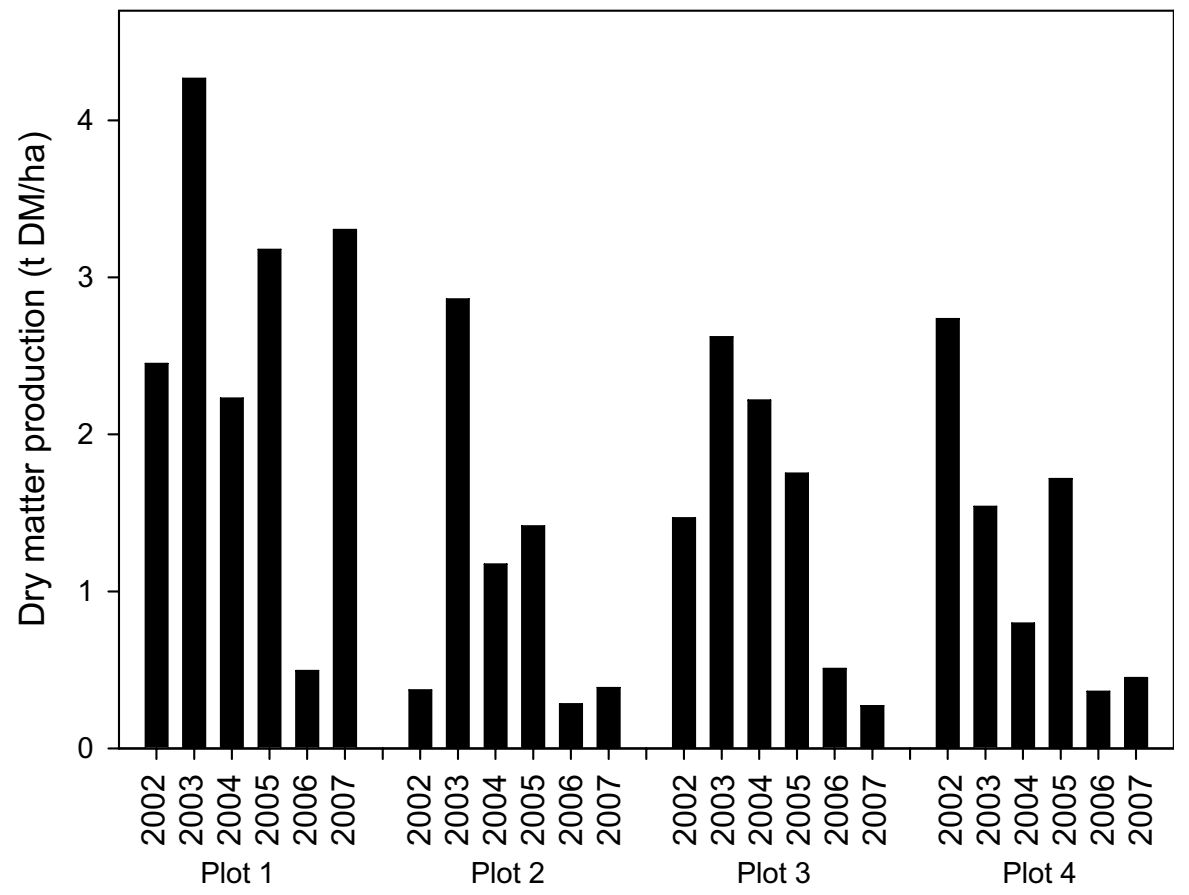

Figure 3 Total annual legume dry matter yield from years 2 to 5 from balansa or subterranean clover from Plots 5 and 6 of cocksfoot based pastures sown in May 2003 in the MaxClover experiment at Lincoln University, Canterbury.

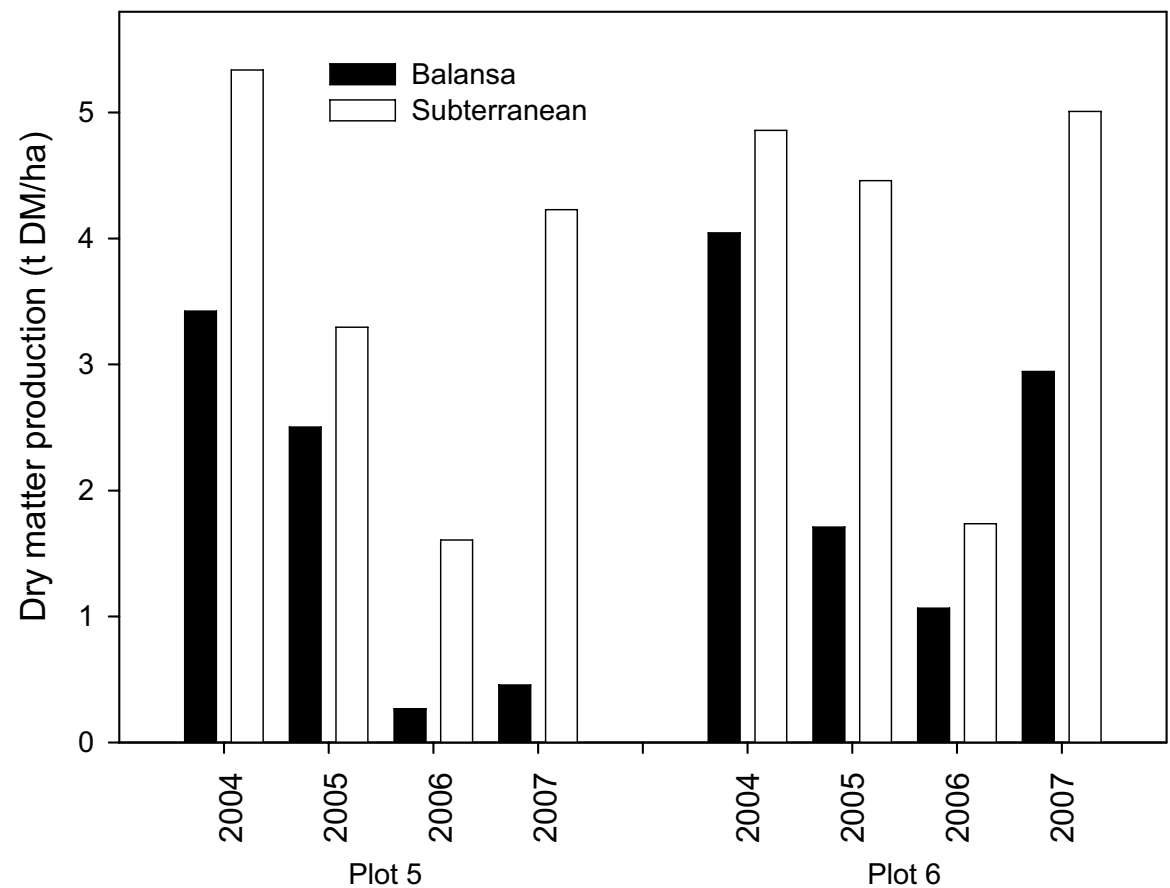




\section{Discussion}

Seedling recruitment in Experiment 1 (Fig. 1) showed that $~ 50 \%$ of the seed set in the first year of flowering emerged after summer rains in December and that $\sim 75 \%$ of all the seed set had emerged by the end of May. By the end of the second autumn $\sim 11 \%$ of the initial seed production remained in the soil, equating to $65 \mathrm{~kg}$ of seed/ha or more than 10 times the amount of seed initially sown. Even allowing for a further $75 \%$ softening in the third season, $16 \mathrm{~kg}$ of seed would still remain hard into the fourth year. Craig \& Ballard (2000) in South Australia and Jansen \& Ison (1996) in western New South Wales produced similar results and showed $50 \%$ of seed was soft at the first break of the season after seed set and $\sim 75 \%$ of seed had emerged by the end of year 1 . These results highlight that sown balansa clover is capable of producing a huge bank of seed that can be managed for regeneration in subsequent years.

The differences in individual plot management within the grazing experiment offer insights into how this seed bank can be managed to maintain balansa clover in a pasture. Plot 1 in the grazed experiment, benefited from the earliest closing date in the establishment year (2002) and later closing for limited seed inputs in the following two seasons. The balansa clover in this pasture contributed the greatest proportion of clover in Year 4 (2005) with $3.3 \mathrm{t} \mathrm{DM} /$ ha (32\% total DM) (Fig. 2). The management for Plot 6 , sown a year later, also produced sufficient seed for balansa clover to be able to re-establish and contribute $2.9 \mathrm{t} \mathrm{DM} / \mathrm{ha}, 3$ years later in 2007 (Fig. 3). This plot had no grazing in 2003 and limited flowering and seeding in 2004. These results show that the potential exists for balansa clover to persist in a grazed pasture with cocksfoot for at least 3 years. The individual grazing management records have identified the need to allow prolific seeding in the establishment year as a key component of balansa clover dry matter productivity in subsequent years.

Plot 5 was managed to contrast with Plot 6 by not allowing seed set in 2004 (Table 1). As a result, Plot 5 produced sufficient seed in 2003 for balansa clover to re-establish for 2 years without significant seed inputs. However, it failed to produce more than $0.5 \mathrm{t} \mathrm{DM} / \mathrm{ha}$ in the third and fourth years (Fig. 3). The failure in the third year coincided with a dry autumn in 2006 which limited annual clover regeneration in all plots (balansa and subterranean) (Mills et al. 2008). Between 6 February 2006 and 24 April 2006 only $77 \mathrm{~mm}$ of rain fell and Penman evapotranspiration totalled $263 \mathrm{~mm}$. It is assumed seedlings that emerged from February rain died before the subsequent rain in late April. This led to low balansa and subterranean clover populations and low spring clover production in the pastures. In a demographic model of clover persistence, Jansen \& Ison (1996) highlighted the sensitivity of balansa clover to low seed production and the risk of false strike. Both of these factors appear to have contributed to the annual clover failures in 2006, when both balansa and subterranean clover had decreased dry matter yields (Fig. 3). It should also be noted that none of the balansa plots were spelled for reseeding in 2005. In that summer season, cocksfoot grass vigour increased (not shown) due to summer rain and the low autumn rainfall gave a false strike in 2006. Hence, 2006 presented a 'worst case' scenario for clover regeneration.

Across the grazing experiment subterranean clover was more productive than balansa when mixed with cocksfoot (Mills et al. 2008, and Fig. 3). However, the performance of the top flowering balansa was encouraging given its limited ability to produce seed when intensively grazed during spring. Other aerial seeding annual clovers such as arrowleaf (Trifolium vesiculosum) and gland clover (T. glanduliferum) also have features which may complement sub clover. Further work should investigate the management requirements of these species plus their ability to increase total legume production in dryland pastures when mixed with sub clover and other perennial grass species.

Our results suggest that balansa clover will be productive for 3 to 4 years in a perennial pasture if it is closed early (mid-September) for heavy re-seeding in the establishment year. This could be achieved by making hay in the establishment season, which is not usually recommended for pasture with perennial clovers. Lenient grazing during warm, moist spring seasons and/or October closing will allow some balansa flowers to set viable seed to extend the contribution of the clover beyond the fourth year.

\section{Conclusions}

Seventy five percent of 'Bolta' balansa clover seed shed on the ground in November had germinated by May of the following autumn. More than 10 times the amount of seed initially sown remained as hard seed in the soil in May of the second year. This hard seed should enable balansa clover to persist in pastures for at least 3 years.

'Bolta' balansa clover averaged $3 \mathrm{t} \mathrm{DM} / \mathrm{ha} /$ year for at least 4 years when sown with cocksfoot on a soil with $160-180 \mathrm{~mm}$ plant-available water capacity in lowland Canterbury. To achieve this, it was sown in autumn and closed in September to flower and set seed. In subsequent favourable seasons, closing in October for 8 weeks added limited amounts of fresh seed to the seed bank. This management prolonged the contribution of balansa clover to the pasture. Seedling survival each autumn is enhanced by intensive summer grazing of the grass to remove most herbage from the soil surface and reduce competition for light and moisture. 


\section{ACKNOWLEDGEMENTS}

Meat and Wool New Zealand Ltd. provided funding for the MaxClover grazing experiment and $\mathrm{PhD}$ scholarship for D.P. Monks.

\section{REFERENCES}

Brown, H.E.; Moot, D.J.; Lucas, R.J.; Smith, M. 2006. Sub clover, cocksfoot and lucerne combine to improve dryland stock production. Proceedings of the New Zealand Grassland Association 68: 109-115.

Brown, H.E.; Moot, D.J.; Pollock, K.M. 2003. Long term growth rates and water extraction patterns of dryland chicory, lucerne and red clover. Legumes for Dryland Pastures. Grassland Research and Practice Series 11: 91-99.

Craig, A.D. Ballard, R.A. 2000. Balansa clover (Trifolium michelianum) - a forage legume for temperate pastures. Cahiers Options Mediterraneennes 45: 177-180.

Dear, B.S. 2003. Australian experience with cool season annual legumes - the challenge to develop environmentally sustainable farming systems. Legumes for Dryland Pastures. Grassland Research and Practice Series 11: 51-59.

Jansen, P.I.; Ison, R.L. 1996. Population dynamics of Trifolium balansae and T. resupinatum in selfregenerating pasture. I. Seed and plant densities and dry matter yield. Journal of Applied Ecology 33: 12411250.

Mills, A.; Smith, M.C.; Lucas, R.J.; Moot, D.J. 2008. Dryland pasture yields and botanical composition over 5 years under sheep grazing in Canterbury. Proceedings of the New Zealand Grassland Association 70: 37-44. 